\title{
KEPUTUSAN MAHASISWA DALAM MEMILIH PERGURUAN TINGGI DITINJAU DARI ANALISIS BAURAN PEMASARAN DAN PERILAKU KONSUMEN
}

\author{
Oleh: \\ Kuntari ${ }^{1)}$; Sumardi') \\ Sekolah Tinggi Ilmu Ekonomi IPWI Jakarta \\ Email: blungtong@gmail.com ${ }^{1)}$; sumardi5214@yahoo.co.id²)
}

\begin{abstract}
ABSTRAK
Bauran Pemasaran dan Perilaku Konsumen adalah dua hal dari beberapa faktor yang diduga relatif besar dalam memengaruhi keputusan Mahasiswa memilih perguruan tinggi pada Sekolah Tinggi Ilmu Ekonomi IPWI Jakarta kampus 2 Cikeas. Guna mendukung hipotesis tersebut maka dilakukan penelitian untuk mengetahui seberapa besar pengaruh Bauran Pemasaran dan Perilaku Konsumen terhadap Keputusan Mahasiswa Memilih Perguruan Tinggi.

Penelitian dilakukan pada Sekolah Tinggi Ilmu Ekonomi IPWI Jakarta kampus 2 Cikeas, menggunakan random/probability tehnik sampling dengan target Mahasiswa Strata 1 sebanyak 90 responden yang dihitung menggunakan rumus Slovin dari total populasi 859 Mahasiswa pada margin error 10\%. Pengambilan data dengan instrumen kuesioner tertutup lima skala penelitian dari sangat tidak setuju hingga sangat setuju. Penelitian dilakukan secara kuantitatif yaitu dengan mendeskripsikan data penelitian dan melakukan analisis inferensi. Analisis korelasi berganda (R2) dan analisis regresi berganda digunakan sebagai alat analisis sedangkan pengujian hipotesis dilakukan menggunakan uji-t dan uji-F.

Penelitian menghasilkan persamaan regresi bahwa Bauran Pemasaran dan Perilaku Konsumen mempunyai pengaruh positif terhadap Keputusan Mahasiswa Memilih Perguruan Tinggi Pada Sekolah Tinggi Ilmu Ekonomi IPWI Jakarta Kampus 2 Cikeas dengan hasil $Y=0,622+0,672 X 1+0,157 X 2$ sehingga sesuai dengan hipotesis. Hasil pengujian signifikansi $t$ menghasilkan bahwa Bauran Pemasaran mempunyai pengaruh signifikan sedangkan perilaku konsumen tidak signifikan.

Berdasarkan hasil temuan tersebut maka upaya memformulasikan strategi bauran pemasaran menjadi prioritas.

Kata kunci:

Bauran Pemasaran, Perilaku Konsumen, Keputusan Membeli/Memilih

Submit: 31 Januari 2019

Review: 26 April 2019

Publish: 30 April 2019

\section{PENDAHULUAN}

Pada era modern dewasa ini dengan tingkat persaingan yang tinggi, proses

pasar sudah tidak dapat berjalan dengan apa adanya (naturally) sehingga diperlukan suatu proses saling
\end{abstract}


mempengaruhi antara penjual dan pembeli yang disebut dengan pemasaran.

Peluang pasar (market size) dari usia belajar jenjang perguruan tingi di Indonesia masih sangat besar. Hal ini dapat dilihat dari prosentase Angka Partispasi Sekolah (APS) untuk usia 19 sampai dengan 24 tahun yang terus meningkat dari tahun ke tahun seiring dengan berkembangnya kelas menengah di Indonesia. Hal ini menunjukkan bahwa kesadaran untuk mendapatkan pendidikan tinggi dalam kurun waktu lima tahun terus meningkat dan harus diimbangi oleh ketersediaan lembaga pendidikan yang sesuai kebutuhan dan bermutu.

Sebagai salah satu penyedia jasa pendidikan Sekolah Tinggi Ilmu Ekonomi IPWI Jakarta tentu melihat peluang pasar yang besar pada jenjang pendidikan tinggi ini. Dalam rangka membangun positioning pada pasar jasa pendidikan, Sekolah Tinggi Ilmu Ekonomi IPWI Jakarta juga mengalami proses interaksi dengan lingkungan dan pasar sasaran. Interaksi ini mendorong Sekolah Tinggi Ilmu Ekonomi IPWI Jakarta membangun suatu ekuitas merk (branding) dan mengemasnya dalam suatu pemasaran yang inovatif dengan visi "Menjadi perguruan tinggi yang menginspirasi mahasiswa memiliki kemampuan manajerial dan jiwa kewirausahaan yang berkarakter pada tahun 2020".

Usaha tersebut juga mengacu kepada konsep pemasaran jasa yang menyebutkan bahwa sistem pemasaran jasa merupakan bagian dalam Total Marketing Plan yang mengacu kepada dua proses yang komprehensif antara perekrutan mahasiswa secara tradisional dan survey pemasaran yang terdiri dari survey mengenai calon mahasiswa, analisa citra (image), pemahaman mengenai siklus permintaan, studi mengenai profile mahasiswa dan komunitasnya, evaluasi program dan surveiretention.

Inovasi pemasaran

yang

dikembangkan antara lain berupa: pemilihan lokasi kampus yang mudah terjangkau (Place), biaya terjangkau (Price), Civitas Akademika yang handal (People), Bangunan kampus yang representatif (Physical Evidence), Promosi yang terarah (Promotion), dan lain sebagainya. Hal-hal tersebut menjadi faktor pendorong Mahasiswa memutuskan memilih belajar di perguruan tinggi ini seperti diungkap secara verbal oleh beberapa Mahasiswa Sekolah Tinggi Ilmu Ekonomi IPWI Jakarta Kampus 2 Cikeas, yang mengatakan bahwa keputusan mereka memilih kampus ini antara lain: lokasi mudah terjangkau, biaya kuliah terjangkau, dan pengaruh periklanan, referensi teman, dan banyak lagi. Pilihan tersebut juga didasari pada karakteristik perilaku mahasiswa seperti persepsi pribadi terhadap beberapa alumni Sekolah Tinggi Ilmu Ekonomi IPWI Jakarta yang menjadi figur di masyarakat, adanya proses belajar mengajar yang fleksibel bagi kelas karyawan, dan persepsi terhadap ekuitas merk (branding) dari Sekolah Tinggi Ilmu Ekonomi IPWI Jakarta yang telah memenuhi standar mutu akreditasi Badan Akreditasi Nasional Perguruan Tinggi(BAN-PT).

\section{TUJUAN PENELITIAN}

Untuk menguji pengaruh bauran pemasaran dan perilaku konsumen terhadap keputusan memilih perguruan tinggi.

\section{TELAAH LITERATUR DAN PENGEMBANGAN HIPOTESIS}

Kotler dan Keller (2016) mengatakan bahwa para ahli ekonomi menggambarkan pasar sebagai kumpulan pembeli dan 
penjual yang melakukan transaksi atas sebuah produk atau kelompok produk tertentu.

Dalam kondisi persaingan yang ketat, maka interaksi dari penjual dan pembeli akan semakin komplek, sehingga diperlukan suatu pendekatan baru yang disebut dengan pemasaran. Pemasaran merupakan sebuah konsep ilmu dalam strategi bisnis yang bertujuan untuk mencapai kepuasan berkelanjutan dari stakeholder (pelanggan, karyawan, dan pemegang saham). Ali Hasan (2014) lebih lanjut mengatakan bahwa sebagai strategi bisnis,pemasaran (marketing) merupakan tindakan penyesuaian suatu organisasi yang berorientasi pasar dalam menghadapi kenyataan bisnis baik dalam lingkungan mikro maupun dalam lingkungan makro yang terus berubah.

Konsumen adalah pengguna barang dan atau jasa yang tersedia dalam masyarakat, baik bagi kepentingan diri sendiri, keluarga, orang lain maupun makluk hidup lain, Konsumen akan mempunyai suatu harapan terhadap produk untuk memenuhi kebutuhannya. Ali Hasan (2014) menjelaskan bahwa harapan atas kinerja produk berlaku sebagai standar perbandingan terhadap kinerja aktual produk. Lebih lanjut dijelaskan, harapan pelanggan ini akan terus berkembang sesuai perubahan lingkungan yang memberi informasi dan bertambahnya pengalaman konsumen yang akan berpengaruh terhadap tingkat kepuasan konsumen. Harapan konsumen diyakini mempunyai peranan yang besar dalam menentukan kualitas produk dan kepuasan konsumen.

\section{Keputusan Pembelian}

Dalam memutuskan suatu pembelian barang atau jasa konsumen melakukan beberapa proses atau tahapan-tahapan baik secara kualitatif maupun kuantitatif.
Tahapan-tahapan ini dilakukan atas usaha atau inisiatif sendiri maupun melalui referensi. Schiffman dan Kanuk (2010) dalam Vinna Sri Yuniarti (2015) mendifinisikan keputusan sebagai pemilihan suatu tindakan dari dua atau lebih pilihan alternatif.

Secara sederhana pembahasan berikut akan memberikan gambaran lebih jelas terkait proses keputusan pembelian.

1. Pengenalan Masalah

Masalah merupakan hasil dari adanya perbedaan antara keadaan yang diinginkan dan keadaan sebenarnya. Sumber pengenalam masalah bisa meliputi adanya perubahan kebutuhan ataupun keinginan, ataupun induksi dari pemasar (marketer).

2. Mencari Informasi

Setelah konsumen mengakui bahwa mereka mempunyai masalah, mereka mencari informasi tentang produk dan layanan yang dapat memecahkan masalah itu. Pencarian informasi dilakukan baik secara internal (memori), dan pencarian eksternal melalui sumber pribadi, sumber publik, atau pengalaman pribadi.

3. Evalausi Alternatif

Pada tahap ini konsumen membandingkan berbagai merek dan produk yang masuk dalam pertimbangan.

4. Keputusan Pembelian

Setelah dievaluasi konsumen siap melakukan pengambilan keputusan

5. Evaluasi Purnabeli

Evaluasi berupa perbandingan antara kinerja produk dengan harapan yang dimiliki oleh konsumen terhadap produk tersebut. Jika produk sesuai harapan maka konsumen akan bereaksi positif seperti memberikan referensi ke orang lain untuk ikut membeli, sebaliknya jika harapan 
tidak sesuai maka konsumen akan bereaksi negatif.

\section{Bauran Pemasaran}

Dalam pemasaran terdapat strategi pemasaran yang disebut dengan bauran pemasaran atau marketing mix yang memiliki peranan penting dalam memengaruhi konsumen agar dapat membeli suatu produk atau jasa yang ditawarkan oleh perusahaan/produsen. Bauran pemasaran seperti Elemen-elemen bauran pemasaran terdiri dari semua variabel yang dapat dikontrol untuk dapat memuaskan para konsumen.

Beberapa pengertian bauran pemasarn menurut para ahli antara lain menurut Buchari Alma (2007) mengatakan bahwa marketing mix adalah strategi mencampur kegiatan-kegiatan marketing, agar dicari kombinasi maksimal sehingga mendatangkan hasil yang paling memuaskan. Sementara lebih spesifik Kotler dan Amstrong (2012) menjelaskan bahwa bauran pemasaran adalah perangkat pemasaran yang baik yang meliputi produk, penentuan harga, promosi, distribusi, digabungkan untuk menghasilkan respon yang diinginkan pasar sasaran.

\section{Produk (Product)}

Produk merupakan elemen penting dalam sebuah program pemasaran. Strategi produk dapat memengaruhi strategi pemasaran lainnya. Pembelian sebuah produk bukan hanya sekedar untuk memiliki produk tersebut tetapi juga untuk memenuhi kebutuhan dan keinginan konsumen. Sehingga keunggulan produk bisa berupa variasi produk, kualitas, disain, fitur, nama merek, kemasan, ukuran, layanan, garansi, dan retur. Kualitas produk merupakan salah satu yang dapat mendorong minat beli konsumen (Raharjo \& Mulyanto, 2018)

\section{Harga (Price)}

Bagi konsumen, bahwa harga merupakan segala bentuk biaya moneter yang dikorbankan konsumen untuk memperoleh, memiliki, memanfaatkan sejumlah kombinasi dari barang beserta pelayanan dari suatu produk atau jasa. Selain itu harga salah satu faktor penting konsumen dalam mengambil keputusan untuk melakukan transaksi atau tidak.

Harga dikatakan mahal, murah atau biasa-biasa saja dari setiap individu tidaklah harus sama, karena tergantung dari persepsi individu yang dilatar belakangi oleh lingkungan kehidupan dan kondisi individu. Faktor harga juga meliputi harga katalog, diskon, potongan khusus, periode pembayaran, dan persyaratan kredit.

\section{Promosi (Promotion)}

Promosi adalah kegiatan mengkomunikasikan informasi dari penjual kepada konsumen atau pihak lain dalam saluran penjualan untuk mempengaruhi sikap dan perilaku. Melalui periklanan suatu perusahaan mengarahkan komunikasi persuasif pada pembeli sasaran dan masyarakat melalui media-media yang disebut dengan media massa seperti koran, majalah, tabloid, radio, televisi dan directmail.

Media promosi yang dapat digunakan pada bisnis ini antara lain (1) periklanan, (2) promosi penjualan, (3) publisitas dan hubungan masyarakat, dan (4) pemasaran langsung. Penentuan media promosi yang akan digunakan didasarkan pada jenis dan bentuk produk itu sendiri. Promosi dapat membuat konsumen tertarik yang pada akhirnya akan meningkatkan penjualan dengan kata lain bauran promosi seperti pameran, personal selling dan iklan media dapat mendorong penjualan perusahaan (Echsanullah \& Wulandari, 2018) 


\section{Saluran distribusi (Place)}

Saluran distribusi terdiri dari seperangkat lembaga yang melakukan segala kegiatan (fungsi) yang digunakan untuk menyalurkan produk dan status pemiliknya dari produsen ke konsumen.

Distribusi berkaitan dengan kemudahan memperoleh produk di pasar dan tersedia saat konsumen mencarinya. Distribusi memperlihatkan berbagai kegiatan yang dilakukan perusahaan untuk menjadikan produk atau jasa diperoleh dan tersedia bagi konsumen sasaran. Dalam kaitan produk jasa pendidikan saluran distribusi mengarah pada kemudahan akses lokasi fisik penyedia jasa berada.

\section{Partisipan (People)}

Yang dimaksud partisipan disini adalah karyawan penyedia jasa layanan maupun penjualan, atau orang-orang yang terlibat secara langsung maupun tidak langsung dalam proses layanan itu sendiri, misalnya dalam jasa pendidikan terdiri dari guru atau dosen, tenaga administrasi, penjaga keamanan. Danang Sunyoto dan Fathonah Eka Susanti (2015) menjelaskan bahwa orang-orang merupakan unsur penting, baik dalam produksi maupun penyampaian kebanyakan jasa. Orangorang secara bertahap menjadi bagian diferensiasi yang mana perusahaanperusahaan jasa mencoba menciptakan nilai tambahan dan memperoleh keunggulan kompetitif.

\section{Proses (Process)}

Proses adalah kegiatan yang menunjukkan bagaimana pelayanan diberikan kepada konsumen selama melakukan pembelian barang. Pengelola usaha melalui front liner sering menawarkan berbagai macam bentuk pelayanan untuk tujuan menarik konsumen. Fasilitas jasa konsultasi gratis, pengiriman produk, creditcard, card member dan fasilitas layanan yang berpengaruh pada image perusahaan. Dalam produk jasa pendidikan hal ini juga proses belajar mengajar, proses registrasi dan seterusnya.

Proses merupakan seluruh prosedur, mekanisme dan kebiasaan di mana sebuah jasa diciptakan dan disampaikan kepada pelanggan, termasuk keputusan kebijakan tentang beberapa keterlibatan pelanggan dan persolan-persoalan keleluasaan karyawan, Danang Sunyoto dan Fathonah Eka Susanti (2015).

\section{Lingkungan fisik (Physical Evidence)}

Lingkungan fisik adalah keadaan atau kondisi yang di dalamnya juga termasuk suasana. Karakteristik lingkungan fisik merupakan segi paling nampak dalam kaitannya dengan situasi. Yang dimaksud dengan situasi ini adalah situasi dan kondisi geografi dan lingkungan institusi, dekorasi, ruangan, suara, aroma, cahaya, cuaca, pelatakan dan layout yang nampak atau lingkungan yang penting sebagai obyek stimuli.

\section{Perilaku Konsumen}

Dalam pemasaran (marketing), perilaku konsumen merupakan bidang kajian untuk menjelaskan bagaimana orang membeli, apa yang mereka beli, kapan mereka beli, dan mengapa mereka membeli dengan cara memadukan unsurunsur psikologi, sosiologi, sosiopsikologis, antropologi, untuk memahami konsumen dalam melakukan keputusan pembelian.

Menurut Ali Hasan (2014) tindakan konsumen tersebut dimaknai dengan driver atau pendorong konsumen yang terdiri dari faktor karakteristik konsumen dan faktor proses psikologi dari konsumen yang secara singkat dijelaskan sebagai berikut : 
Faktor karakteristik konsumen meliputi:

1. Budaya (Culture), yaitu sekumpulan nilai, persepsi, preferensi, dan perilaku tertentu yang diperoleh dari lingkungan keluarga, agama, kebangsaan, ras dan geografis.

2. Kelas sosial (Social class), yaitustratifikasi atau kelas sosial tertentu. Yang dimaksud kelas sosial adalah pembagian kelompok masyarakat yang relatif homogen dan permanen yang tersusun secara sistematis, anggotanya menganut nilai, minat, dan perilaku yang serupa.

3. Kelompok acuan (Reference group), yaitu seseorang dalam kelompok tertentu yang memiliki pengaruh langsung terhadap sikap dan perilaku anggota kelompok atau komunitas.

Sehingga dapat disimpulkan bahwa perilaku konsumen adalah tindakantindakan dari konsumen yang berhubungan dengan proses memilih, membeli, menggunakan atau mengelola (dispose) produk, jasa atau ide dalam pemenuhan kebutuhan dan keinginannya. Tindakan ini didorong oleh faktor karakteristik konsumen yang terdiri dari budaya, kelas sosial, kelompok acuan dan dipengaruhi oleh faktor psikologis berupa motivasi, persepsi, sikap dan pembelajaran.

\section{Pemasaran Jasa Pendidikan Perguruan Tinggi}

Sebagai pemberi layanan jasa pendidikan, perguruan tinggi mempunyai karasteristik unik sebagaimana dijelaskan dalam Danang Sunyoto dan Fathonah Eka Susanti (2015) sebagai berikut:

1. Perguruan tinggi termasuk ke dalam kelompok jasa murni, dimana pemberian jasa yang dilakukan didukung alat kerja atau sarana pendukung semata seperti ruang kelas, kursi, meja, dan sebagainya.

2. Jasa yang diberikan memerlukan kehadiran pengguna jasa (mahasiswa)

3. Penerima jasa adalah orang, jadi pemberian jasa yang berbasis orang. Pelanggan dengan pemberi jasa terus berinteraksi selama proses pemberian jasa berlangsung.

4. Hubungan dengan pelanggan berdasarkan hubungan keanggotaan (member relationship) dimana pelanggan telah menjadi anggota lembaga pendidikan tertentu.

Keputusan paling mendasar yang dibuat perguruan tinggi adalah program dan jasa apa yang akan ditawarkan kepada mahasiswa, alumni, donatur, dan masyarakat lainnya. Dalam membuat program dan jasa perlu diketahui siklus yang meliputi:

1. Tahap perkenalan (introduction) yaitu periode dimana terjadi pertumbuhan lambat karena program baru diperkenalkan kepada masyarakat (calon mahasiswa) di pasar.

2. Tahap pertumbuhan (growth) yaitu periode di mana terjadi penerimaan yang cepat dari suatu program.

3. Tahap kematangan (maturity) yaitu periode di mana terjadi perlambatan dalam pertumbuhan karena program yang dimiliki sudah diterima oleh banyak konsumen potensial.

4. Tahap penurunan (decline) yaitu periode di mana terjadi penurunan ketertarikan dari konsumen.

Lembaga pendidikan dalam hal ini perguruan tinggi swasta khususnya adalah salah satu institusi yang mengembangkan sistem pemasaran untuk menarik minat calon mahasiswa. Buchari Alma (2007) menyebutkan bahwa sistem ini merupakan bagian dalam total marketing plan. Selanjutnya Paul Jedamus dalam Buchari Alma (2007) menjelaskan arti total 
marketing plan harus menjadi bagian dari rencana instistusi yang lebih besar. Total marketing plan mengacu kepada dua proses yang komprehensif antara perekrutan mahasiswa secara tradisional dan survey pemasaran yang terdiri dari survey mengenai calon mahasiswa, analisa citra (image), pemahaman mengenai siklus permintaan, studi mengenai profil mahasiswa dan komunitasnya, evaluasi program dan survey retention.

Elemen bauran pemasaran jasa pendidikan menurut Buchari Alma (2007) terdiri dari 4P tradisional (Product, Price, Place, Promotion) ditambah 3 elemen $\mathrm{P}$ (Physical Evidence,Process, People) memengaruhi calon mahasiswa sehingga mereka mau mendaftar masuk perguruan tinggi. Informasi tentang $7 \mathrm{P}$ tersebut akan diperoleh calon mahasiswa melalui berbagai sumber seperti media masa, orang tua, family, alumni, guru, dan sebagainya.

Masing-masing elemen 7P jasa pendidikan dapat dijabarkan seperti: Produk (Product), merupakan penentu utama(the most crucial determinat) yang menjadi pertimbangan preferensi pilihan mahasiswa. Citra perguruan tinggi, kualitas alumni, dan jurusan merupakan bagian dari produk.Harga (Price), elemen ini sejalan dengan mutu produk. Masuk kategori ini adalah biaya kuliah secara keseluruhan. Lokasi (Place), letak perguruan tinggi yang mudah dicapai dengan kendaraan umum cukup berperan sebagai pertimbangan calon mahasiswa memilih perguruan tinggi.Promosi (Promotion), masih menurut Buchari Alma (2007) bahwa promosi mempunyai korelasi negative terhadap daya tarik peminat.Lingkungan Fisik (Physical Evidence), berupa tampilan bangunan, arsitektur bangunan, laboratorium, perpustakaan, sarana olahraga, taman.Partisipan/orang (People), ini dapat berupa unsur pimpinan perguruan tinggi, dosen, dan jajaran karyawan yang melayani mahasiswa.Proses (Process), yaitu proses yang dialami mahasiswa dalam menempuh pendidikan meliputi contoh: proses perkuliahan, proses registrasi, proses bimbingan skripsi, proses wisuda dan sebagainya.

\section{METODE PENELITIAN \\ Sampel Penelitian}

Populasi dan Teknik Pengambilan Sampel. Populasi dalam penelitian ini adalah mahasiswa Program Strata Satu (S1) aktif pada kampus 2 Sekolah Tinggi Ilmu Ekonomi IPWI Jakarta.hingga bulan Desember 2016 sejumlah 859 orang. Adapun sampel dengan bantuan rumus Slovin dengan tingkat toleransi error $10 \%$ sejumlah 90 orang.

\section{Pengumpulan Data}

Instrument Penelitian ini menggnakan angket atau kuesioner yang sifatnya tertutup karena jawaban kuesioner tersebut sudah tersedia berupa pilihan yaitu 1-5

Teknik pengumplan data yang digunakan pada penelitian ini adalah sebagai berikut : Teknik Angket dan Teknik Dokumentasi

\section{Analisis}

Adapun Analisis Data dan Uji Hipotesis dalam penelitian ini adalah :

1. Uji validitas dan Reliabilitas, dilakukan untuk memastikan instrument penelitian sebagai alat ukur yang akurat dan dapat dipercaya. Validitas menunjukkan sejauhmana suatu alat ukur, mengukur apa yang ingin diukur. Sedangkan Reliabilitas menunjukkan sejauhmana suatu hasil pengukuran relative konsisten apabila pengukuran terhadap aspek yang 
sama atau disebut juga internal consistency reliability.

2. Uji Asumsi Klasik terdiri dari : Uji Normalitas data, Uji Heteroskedastisitas, Uji Multikolonieritas dan Uji Autokorelasi.

3. Uji Korelasi (r) \& Korelasi Berganda ( R )

4. Analisis Regresi Linear Berganda

5. Analisis Hipotesis

\section{HASIL DAN PEMBAHASAN Hasil Penelitian Pengujian Validitas dan Reliabilitas}

1. Variabel X1 seluruhnya lebih besar dari rtabel $=0.207$ sehingga seluruh pertanyaan dinyatakan valid. Variabel X2 dimana hasil olah SPSS menunjukkan kesimpulan dari variable $\mathrm{X} 2$ diperoleh bahwa nilai rhitung $>$ rtabel $(0,207)$ sehingga sepuluh butir pertanyaan variable $\mathrm{X} 2$ dinyatakan valid. Variabel Y dimana hasil olah SPSS menunjukkan kesimpulan dari variable $\mathrm{Y}$ diperoleh bahwa nilai rhitung> rtabel $(0,207)$ sehingga lima butir pertanyaan variable $\mathrm{Y}$ dinyatakan valid.

2. Nilai Cronbach's Alpha sebesar 0.811, dan interpretasi Uji Reliabilitas dinyatakan dengan 0.811> 0.60 sehingga butir pertanyaan variabel $\mathrm{X} 1$ memenuhi unsur reliabilitas. Cronbach's Alpha sebesar 0.637, dan interpretasi Uji Relaibilitas dinyatakan dengan $0.637>0.60$ sehingga butir pertanyaan variabel X2 memenuhi unsur reliabilitas. Cronbach's Alpha sebesar 0.660, dan interpretasi Uji Reliabilitas dinyatakan dengan 0.660> 0.60 sehingga butir pertanyaan variabel $Y$ memenuhi unsur reliabilitas.

\section{Uji Asumsi Klasik}

1. Hasil Uji Normalitas

Nilai Kolmogorov-Smirnov untuk Variabel Bauran Pemasaran adalah 0.196 yang berarti lebih besar dari nilai signifikansi 0.05 atau pernyataan statistik dengan $0.196>0.05$, sehingga data variabel Bauran Pemasaran dinyatakan berdistribusi normal. Variabel Perilaku Konsumen diperoleh nilai 0.452 yang berarti lebih besar dari nilai signifikansi 0.05 atau pernyataan statistik dengan 0.452> 0.05 , sehingga sebesar 0,173 yang berarti lebih besar dari nilai signifikansi 0.05 atau pernyataan statistik dengan 0,173>0,05, sehingga data variabel Keputusan Mahasiswa Memilih Perguruan Tinggi dinyatakan berdistribusi normal.

2. Hasil Uji Multikolinieritas

Nilai VIF variabel Bauran Pemasaran sebesar 1,132 dan nilai VIF variabel Perilaku Konsumen sebesar 1,132. Angka tersebut masuk dalam jangkauan (range)angka 1 - 10 sehingga dapat disimpulkan bahwa data dari kedua variabel bebas tidak terjadi multikolinieritas.

3. Hasil Uji Autokorelasi

Nilai Durbin-Watson tabel dengan jumlah variabel independne (k2) dan jumlah sample (n) 90 diketahui nilai $\mathrm{du}=1,612$ dan nilai $\mathrm{dl}=1,703$. Dari data diketahui bahwa nilai dhitung adalah 2,286 sehingga keputusannaya adalah:

du $<$ dhitung $<4$-du

$1,612<2,286<(4-1,612)$

$1,612<2,286<2,388$

Sehingga data variabel tidak terjadi autokorelasi dengan kata lain suatu data sample tidak dipengaruhi oleh data sample sebelumnya. 
4. Hasil Uji Heteroskedastisitas

Grafik Scatterplot menunjukkan pola titiknya memenuhi kriteria tersebut diatas, sehingga diismpulkan bahwa data tidak terjadi heteroskedastisitas.

\section{Analisis dan Pembahasan Uji Model}

$$
\begin{aligned}
& \text { Kemampuan model dalam } \\
& \text { menjelaskan pengaruh variable } \\
& \text { independen terhadap variable dependen } \\
& \text { ditunjukkan oleh output statistic sebagai } \\
& \text { berikut: }
\end{aligned}
$$

Tabel 1

Koefisien Determinasi

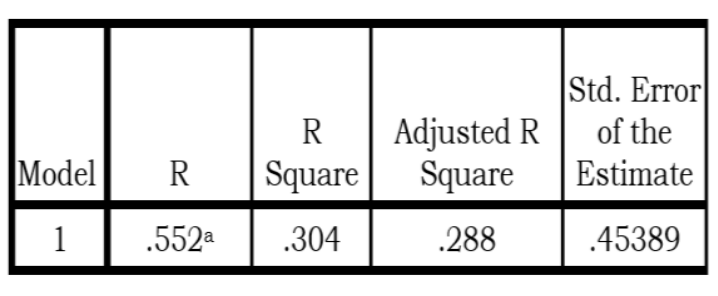

Kemampuan model dalam menjelaskan pengaruh Bauran Pemasaran dan Perilaku konsumen terhadap Keputusan Mahasiswa Memilih Perguruan Tinggi ditunjukkan oleh nilai koefisien determinasi sebesar 0,304. Keputusannya adalah Bauran Pemasaran dan Perilaku Konsumensecara bersama-sama mampu menjelaskan 30,4\% Keputusan Mahasiswa Memilih Perguruan Tinggi Sekolah Tinggi Ilmu Ekonomi IPWI Jakarta.

Pengujian kelayakan model dilakukan

\begin{tabular}{|c|c|c|c|c|c|c|}
\hline \multicolumn{2}{|c|}{ Model } & $\begin{array}{l}\text { Sum } \\
\text { of } \\
\text { Squar } \\
\text { es }\end{array}$ & df & $\begin{array}{c}\text { Mean } \\
\text { Square }\end{array}$ & $\mathrm{F}$ & Sig. \\
\hline \multirow[t]{3}{*}{1} & $\begin{array}{l}\text { Regre } \\
\text { ssion }\end{array}$ & 7.841 & 2 & 3.920 & 19.030 & .000 \\
\hline & $\begin{array}{l}\text { Resid } \\
\text { ual }\end{array}$ & $\begin{array}{c}17.92 \\
3\end{array}$ & 87 & .206 & & \\
\hline & Total & $\begin{array}{c}25.76 \\
4\end{array}$ & 89 & & & \\
\hline
\end{tabular}
berdasar output statistic berikut:

Tabel 2

Uji Signifikansi Model ANOVA $^{\text {b }}$
Dari data diatas diketahui bahwa nilai Fhitung 19,030 dengan nilai signifikansi 000a. Disimpulkan bahwa Bauran Pemasaran dan Perilaku Konsumen secara bersama-sama mempunyai pengaruh signifikan terhadap Keputusan Mahasiswa Memilih Perguruan Tinggi Pada Sekolah Tinggi Ilmu Ekonomi IPWI Jakarta Kampus 2 Cikeas.

\section{Analisis dan Uji Parsial}

Analisis dan uji pengaruh antar

\begin{tabular}{|c|c|c|c|c|c|}
\hline \multirow[b]{2}{*}{ Model } & \multicolumn{2}{|c|}{$\begin{array}{l}\text { Unstandardi } \\
\text { zed } \\
\text { Coefficients }\end{array}$} & \multirow{2}{*}{ 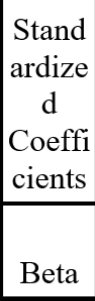 } & \multirow[b]{2}{*}{$\mathrm{t}$} & \multirow[b]{2}{*}{ Sig. } \\
\hline & B & Error & & & \\
\hline 1 (Constant) & .622 & .600 & & 1.038 & .302 \\
\hline $\begin{array}{l}\text { Bauran } \\
\text { Pemasaran }\end{array}$ & .672 & .127 & .504 & 5.297 & .000 \\
\hline $\begin{array}{l}\text { Perilaku } \\
\text { Konsumen }\end{array}$ & .157 & .135 & .111 & 1.163 & .248 \\
\hline
\end{tabular}
variable secara parsial didasarkan pada output statistic sebagai berikut:

Tabel 3

Analisis Regresi Linier Ganda

1. Nilai $\mathrm{t}$ hitung Bauran Pemasaran adalah 5,297 dengan signifikansi 000 . Hal ini diinterpretasikan sebagai sig $\mathrm{t}$ hitung $(000)<0,05$ sehingga H01 ditolak dan Ha1 diterima. Disimpulkan bahwa Bauran Pemasaran mempunyai pengaruh positif dan signifikan terhadap Keputusan Mahasiswa Memilih Perguruan Tinggi Pada Sekolah Tinggi Ilmu Ekonomi IPWI Jakarta Kampus 2 Cikeas.

2. Nilai $t$ hitungPerilaku Konsumen adalah 1,163 dengan signifikansi 0,248. Hal ini diinterpretasikan sebagai sig $\mathrm{t}$ hitung $(0,248)>0,05$ sehingga H02 
diterima dan Ha2 ditolak. Disimpulkan bahwa Perilaku Konsumen mempunyai pengaruh positif dan tidaksignifikan terhadap Keputusan Mahasiswa Memilih Perguruan Tinggi Pada Sekolah Tinggi Ilmu Ekonomi IPWI Jakarta Kampus 2 Cikeas.

\section{KESIMPULAN}

1. Pengaruh variabel bebas Bauran Pemasaran terhadap variabel terikat Keputusan Mahasiswa Memilih Perguruan Tinggi Pada Sekolah Tinggi Ilmu Ekonomi IPWI Jakarta Kampus 2 Cikeas adalah positif dan signifikan..

2. Pengaruh variable Perilaku Konsumen terhadap variable keputusan mahasiswa memilih Perguruan Tinggi Pada Sekolah Tinggi Ilmu Ekonomi IPWI Jakarta Kampus 2 Cikeas adalah positif dan tidak signifikan.

\section{SARAN}

1. Memberi fokus yang lebih pada usahausaha peningkatan Bauran Pemasaran dengan membuat kombinasi unik pada elemen 7P (Product, Price, Place, Promotion, Process, People, Physical Evidence).

2. Melakukan penelitian lebih mendalam terkait Perilaku Konsumen sehingga dapat memberikan pengaruh yang lebih baik terhadap keputusan mahasiswa memilih perguruan tinggi pada Sekolah Tinggi Ilmu Ekonomi IPWI Jakarta.

\section{DAFTAR PUSTAKA}

Alma, Buchari. (2007). Manajemen Pemasaran dan Pemasaran Jasa. Bandung: Alfabeta

Hasan, Ali. (2014).Marketing dan Kasus Kasus Pilihan.Yogyakarta: Center for Academic Publishing Service (CAPS).

Irwin, Andi. (2013). Pengaruh Bauran Pemasaran Terhadap Keputusan

Pembelian Perumahan GreenPerilla Pada PT. Ciputra Fajar Mitra di Gowa. 26 Juni 2016. https://repository.unhas.ac.id/digilib/ html.

Kotler, Philip; Keller, Kevin Lane. (2016).Manajemen Pemasaran Edisi 12 Jilid 1. Jakarta: PT Indeks.

Ristekdikti. (2016). Data JumlahDosen dan Mahasiswa STIE IPWIJA". 26 Juni 2016. http://forlap.ristekdikti.go.id/mahasis wa. Sekolah Tinggi IImu Ekonomi IPWI Jakarta. (2016). STIE IPWIJA. 26 Juni 2016.http://stieipwija.ac.id.

Sunyoto, Danang; Susanti, Fathonah Eka.(2015).Manajemen Pemasaran Jasa. Yogyakarta: Centre for Academic Publishing Services (CAPS).

Yuniarti, Vinna Sri.(2015).Perilaku Konsumen Teori dan Praktik. Bandung: CV Pustaka Setia.

Echsanullah, M., \& Wulandari, A. (2018). Pameran, Personal Selling dan Iklan Media Online dalam Mendorong Penjualan Property. Jurnal Pengembangan Wiraswasta, 20(3), $12 . \quad$ doi: http://dx.doi.org/10.33370/jpw.v20i3. 266

Raharjo, R. M., \& Mulyanto, H. (2018). Kualitas Produk, Citra Merek dan Minat Beli Konsumen Keripik Singkong. Jurnal Manajemen Kewirausahaan, 15(1), 12 . doi: http://dx.doi.org/10.33370/jmk.v15il . 198 